\title{
REVIEWS
}

Queer Palestine and the Empire of Critique, by

Sa'ed Atshan. Stanford, CA: Stanford University Press, 2020. 294 pp. \$29.42 paper. ISBN: 9781503612396.

\section{SARA SALMAN}

Victoria University of Wellington sara.salman@vuw.ac.nz

At such a polarized moment in American and indeed global history, it seems that social movements face an intense demand for radical purity. Although different notions of what is to be done can allow movements to grow, contemporary pressures for purity have consumed social movements, leaving them no space to effect change in the world. In Queer Palestine and the Empire of Critique, Sa'ed Atshan investigates the impact of what he terms radical purism. He tells the story of the rise and stall of the global queer Palestinian solidarity movement and explores the role of activists and academics in the movement. He focuses on the movement's resistance against patriarchy and anti-queer nationalism in Palestinian society, the pinkwashing of the Israeli-Palestinian conflict, and the movement's struggle to grow against the demands of radical purity.

The queer Palestinian solidarity movement began in 2002 in Israel and the Occupied Palestinian Territories. The movement is a struggle for both national and sexual liberation. The movement grew internationally with connections to global queer movements. It sought to resist Palestinian gender and sexual norms, as well as Israeli occupation of Palestinian territories. Highlighting the struggle of embodying LGBTQ identities in the Occupied Territories and Israel, Atshan offers a nuanced account of homophobia in Palestinian society, one that is deeply connected to displacement, but one which is also actively countered by LGBTQ Palestinians. According to Atshan, through connecting with Israeli and international queer activists, the movement was able to grow. Palestinian queer activists fought for "discursive enfranchisement" and thus attempted to "claim their place within the Palestinian body politic and social fabric, rejecting Zionist and homophobic attempts to negate their existence and struggle" (p. 75).

In this sense, Atshan challenges commonly held (deeply orientalist) assumptions about sexuality in the Middle East. In the first and second chapters, Atshan highlights the impact of pinkwashing, the process by which Israel and western countries legitimate colonialism and military intervention by representing "us" and "them." On one hand, "we" are tolerant and sexually liberated, while on the other, "they" (those colonized and occupied) are fanatical and sexually repressed. Atshan argues that pinkwashing simultaneously conceals oppression in Israeli and western societies and silences resistance to oppression in Palestinian and nonwestern societies. Pinkwatching, which challenges pinkwashing, is one of the ways the queer Palestinian solidarity movement has countered occupation and highlighted queer everyday life in Palestinian and Israeli societies.

Atshan's challenge to orientalist constructions of sexualities in the Middle East is persuasive. It informs readers that queer Palestinians are often targeted in Palestinian Territories for defying patriarchal gender binaries and betraying the national struggle. But they are also targeted in Israel. Israeli law enforcement and intelligence agencies often attempt to recruit queer Palestinians as informants, with the threat of outing them to their communities should they refuse. As such, queer Palestinians live under intense surveillance and hostility in both societies.

Despite growing in the 2000s, the movement was stalled by radical purism. Atshan defines radical purism as the tendency within activism and academia to stifle social movements that subvert monologism (p. 142). In this instance, radical purism aims insurmountable critiques that silence the queer Palestinian movement by placing it in doubt for not being authentically Arab or Palestinian, for being an imitation of 
western movements, and for placing sexual liberation above national liberation by collaborating with Israeli and western activists. As Atshan details throughout the book, none of these critiques reflect the complexity of the everyday life of queer Palestinians, yet they carry a toll.

Distinct from criticism, whereby allies may point to shortcomings that hinder a social movement's growth, critique appears in this instance as smothering. It offers no way out and no path for growth. The empire of critique, which demands radical purity, has succeeded at stunting the growth of the global Palestinian queer solidarity movement. According to Atshan, it did so by identifying any engagement with western and Israeli societies to legitimating oppression. The critique has a chilling effect, preventing dialogue with ideologically different groups.

In narrating the ways in which critiques drown resistance, Atshan does not dismiss critics but addresses them thoughtfully. In the book's third chapter, Atshan discusses persistent conflicts between queer Zionists and anti-Zionists and argues that each side is trapped in radical purity. Queer Zionist activists and queer anti-Zionist activists exchange accusations of anti-Semitism over solutions to the Israeli-Palestinian conflict. The accusations effectively sever dialogue between social justice activists (p. 131). What is at stake in the midst of this conflict is a pluralistic queer rights movement where the demand for freedom is a demand for the freedom of all.

Furthermore, and particularly striking, Atshan investigates a certain brand of western academic critique that rejects Palestinian queerness as such. The critique manifests as antipathy to Palestinian embodied and discursive queerness. It posits that queerness as an identity is a western construct imposed on the Middle East as a form of sexual imperialism and as a mechanism of legitimating colonization and militaristic intervention; therefore, there are no queer Palestinians, and demands for queer liberation are imperialistic. Atshan notes that this overwhelming rejection of the movement takes a paranoid tone: queerness is external to Palestinian society; hence queer Palestinians who are demanding to be recognized as such are assuming the position of the enemy, with deleterious effects to the cause of liberation (p. 195). Succumbing to this logic, some activists in the queer liberation movement have had to disavow its engagement in dialogue with global allies and its core demands for equality. Effectively, the empire of critique functions to discursively and materially disenfranchise the movement. The paranoid demand for purity amounts to surveillance of queer bodies, which both replicates orientalist essentialist constructions of Arab sexuality as being one-dimensional and arrested and exacerbates the marginalization of LGBTQ Palestinians.

Atshan's remarkable analysis exposes the ambivalent position of academia vis-à-vis social movements. Though academics in the humanities and the social sciences tend to support movements for liberation, academics can also occupy a hostile position in relation to them. The insistence on ideological purity and the construct of certain liberation demands as untimely or inauthentic is devastating for activists on the ground who reckon with the reality of occupation and antiLGBTQ oppression. It is a sobering assessment. Yet, Atshan offers a corrective: to hell with the empire of critique. "Queer Palestinian activists should free themselves from trying to fulfil the expectations of Western-based academics who are not partners to any queer Palestinians on the ground" (p. 217). Atshan affirms the necessity of building global solidarity by engaging with western and Israeli activists, resisting monologism, and finding value in dialogue.

Atshan makes a major contribution to the study of social movements generally and the queer Palestinian movement specifically. Atshan conceptually explores resistance and identity in the context of Israeli and Palestinian conflict. He offers an empirically rich and compelling account, where readers are let into the everyday life of the global queer Palestinian solidarity movement.

Atshan is thoughtful when sharing his experiences as an academic and activist in the movement. His ethnographic observations retain the humanity and the complexity of the people sharing their experiences. Narratives of resistance are juxtaposed with dominant discourses on sexuality and the 
material reality of living under occupation. In concluding the book, Atshan warns against ideological purity and offers an alternative path of inclusive social change. As such, the book is useful for academics, activists, and general audiences interested in social movements, queer liberation, and national liberation, as well as issues pertaining to the Israeli-Palestinian conflict.

Beauty Diplomacy: Embodying an Emerging Nation, by Oluwakemi M. Balogun. Stanford, CA: Stanford University Press, 2020. 304 pp. $\$ 28.00$ paper. ISBN: 9781503608856 .

AlKa MENON

Yale University

Alka.menon@yale.edu

Even as beauty pageants have receded from Americans' public consciousness, they continue to captivate audiences worldwide. Oluwakemi Balogun's book, Beauty Diplomacy: Embodying an Emerging Nation, captures some of the magic and glamour of beauty pageants while also demonstrating their effects and relevance on national and global politics and economics. Beauty Diplomacy offers an engaging investigation of the beauty pageant industry in Nigeria, tracing beauty pageants through the realms of entertainment and business as well as soft power and diplomacy. The monograph advances a growing body of work on beauty as a site to explore the tensions between globalization and national identity. Balogun's contribution locates beauty pageants within a specific political, historical, and economic context in Nigeria amid a trajectory of "rising Africa." At the same time, she problematizes the straightforward progress narrative that this label might suggest. Beauty Diplomacy demonstrates how there is much of symbolic and substantive import in pageantry.

Nigeria hosts several beauty pageants, aiming to attract attention by appealing to different niches. Beauty Diplomacy describes two pageant organizations: the Most Beautiful Girl in Nigeria, which touted its ties to international pageants, and Queen Nigeria, which emphasized representing and unifying the nation. Comparing them illustrates the variety of aims and interests behind pageants. As Balogun reminds us, beauty pageants are competitions, culminating in the crowning of winners.

Beauty can be a unifying force for an emerging nation by showcasing unity in diversity, staging coexistence and harmony. The notion of beauty diplomacy emphasizes the positioning of women as cultural ambassadors within a diverse nation and to other nations. This positioning further allows a country to adopt and assert a position of global relevance and stature. Balogun argues that "nation-states are defined in part through embodied debates about globalization and the cultural politics of nation-building" (p. 228). This argument is abundantly supported in the Nigerian case, but it also speaks to the experiences of other emerging nations. When Nigeria seeks success on the global stage of beauty pageants, it is not emulating the West, but rather turning to countries like India or Venezuela for inspiration. Beauty Diplomacy connects the micro and macro levels of beauty culture while also drawing attention to the mediating efforts of industry and nation; Balogun describes beauty diplomacy as providing "a middle-out rather than a top-down perspective" (p. 18), with the industry selectively allying with the state to advance its aims and skirting the state when it believes that would better serve its purposes.

Beauty pageants are also sites of contestation about globalization and national identity. Some feminist scholars have criticized international beauty pageants for exporting western beauty ideals from the United States to the rest of the world. Balogun offers evidence that Nigerian beauty contestants and their groomers and handlers pursue a different set of beauty ideals to appeal to an international audience. However, she also points out that the participation of emerging nations like Nigeria in international beauty pageants can broaden perceptions of beauty and increase awareness of what the country has to offer; at least some ethnic authenticity is desirable, as a marker of exoticism, but also as a marker of difference to be consumed. Accordingly, even as they globalize, nationalize, or regionalize notions of appearance, 